Mitteilungen der Österreichischen Geographischen Gesellschaft, 161. Jg., S. 379-394

(Annals of the Austrian Geographical Society, Vol. 161, pp. 379-394)

Wien (Vienna) 2019, https://doi.org/10.1553/moegg161s379

\title{
What Can the Housing Market Teach Us? University Fieldtrips Identify Current Transitions in Vienna's Urban Development and Housing Market Policies
}

\author{
Elisabeth GRUBER and Yvonne FRANZ, Vienna [Wien]* \\ with 7 figures and 1 table in the text
}

\section{CONTENTS}

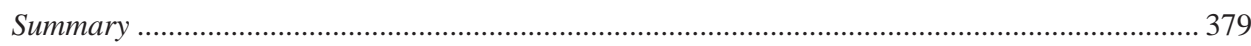

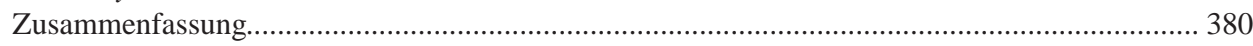

1 Introduction: The Viennese housing market as a must-see for students of human

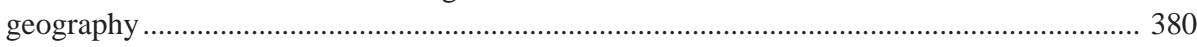

2 Setting the scene: The public and academic discourse on housing market changes in and

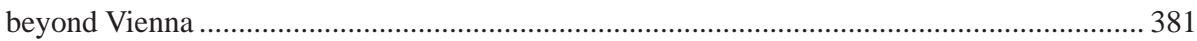

3 Governance: Strategies of the City of Vienna for future affordable housing .......................... 389

4 Didactic benefits of fieldtrips for studying spatial development processes............................ 391

5 Lessons learned: Conclusions from the field ............................................................................ 391

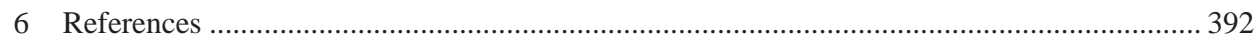

\section{Summary}

Vienna's housing market serves as a posterchild example for affordable and social housing that includes the heritage of the "Red Vienna" housing projects, the city's "Soft Urban Renewal Programme" as well as current housing projects in newly built urban development areas. Today, many European cities are suffering from tight housing markets and increasing rents, so in recent years the success of the housing market in Vienna has become ever more an object of interest. But also the Viennese housing market has been undergoing dynamic transformation in recent years. Although a large number of new dwellings have been created in both, the private and the public sector over the past ten years, rising rents are showing increasing demand for housing. This development is not just caused by growing population numbers, but also by shifting investment interests in the Vienna housing market, which produce affordability and access restrictions. Adequate and affordable housing is currently becoming a challenge for residents in Vienna.

Over four consecutive semesters, Yvonne Franz and Elisabeth Gruber have been collecting evidence for housing market transformations by organising three-day fieldtrips for Master's students at the University of Vienna. In addition to examining recent urban development forms and their

\footnotetext{
* Mag. Dr. Elisabeth Gruber, Institute for Urban and Regional Research, Austrian Academy of Sciences, Postgasse 7/4/2, A-1010 Vienna, Austria; Mag. Dr. Yvonne Franz, Department of Geography and Regional Research, University of Vienna, Universitätsstraße 7, A-1010 Vienna, Austria; Emails: elisabeth.gruber@oeaw. ac.at, yvonne.franz@univie.ac.at
} 
resonance in the wider academic discourse, this article also shows how fieldtrips can be used as an important didactic tool in graduate education.

Keywords: Housing, Vienna, fieldtrip, urban geography

\section{Zusammenfassung}

\section{WAS VERMITTELN WOHNUNGSMÄRKTE? UNIVERSITÄTSEXKURSIONEN IDENTIFIZIEREN AKTUELLE VERÄNDERUNGSPROZESSE DER STADTENTWICKLUNG UND AM WIENER WOHNUNGSMARKT.}

Der Wiener Wohnungsmarkt ist ein internationales Musterbeispiel für bezahlbares und soziales Wohnen. Viel beachtete Wohnungsmarktsegmente sind hier etwa das Erbe des „Roten Wien “ oder der „Sanften Stadterneuerung“. Zahlreiche europäische Städte leiden heute unter angespannten Wohnungsmärkten und steigenden Mieten, so dass der Erfolg des Wiener Wohnungsmarktes in den letzten Jahren wieder mehr in den Fokus des öffentlichen ebenso wie des wissenschaftichen Interesses gerückt ist. Aber auch der Wiener Wohnungsmarkt befindet sich derzeit in einer dynamischen Transformation. Obwohl in den vergangenen zehn Jahren sowohl im privaten als auch im öffentlichen Sektor eine Vielzahl neuer Wohnungen entstanden ist, werden an der steigenden Mietpreisentwicklung sowohl eine zunehmende Wohnraumnachfrage als auch Nachholeffekte im Investitionsbereich sichtbar, die Leistbarkeits- und Zugangsbeschränkungen produzieren. Adäquaten und leistbaren Wohnraum zu finden, wird damit zur Herausforderung für Bewohner und Zuwanderer in Wien.

Im Rahmen mehrtägiger Exkursionen blickten Yvonne Franz und Elisabeth Gruber in den letzten Jahren mit Studierenden des Institutes für Geographie und Regionalforschung an der Universität Wien genauer auf den Wiener Wohnungsmarkt. Im vorliegenden Artikel werden die aktuell beobachtbaren Entwicklungen in Wien dargestellt, die empirisch noch unterrepräsentiert sind obwohl es einen dazugehörigen internationalen Forschungskontext gibt. Zudem wird in diesem Artikel erläutert, warum der Wiener Wohnungsmarkt ein gutes Lehr- und Lernobjekt der Humangeographie darstellt.

Schlagwörter: Wohnungsmarkt, Wien, Exkursion, Stadtgeographie

\section{Introduction: The Viennese housing market as a must-see for students of human geography}

Every year, hundreds of governmental delegates, politicians, municipal employees, architects and planners from around the world visit Vienna to study its housing policies. Being a model city for social and affordable housing, Vienna's example includes the heritage of the "Red Vienna" (19191934) housing projects (e.g., Reumannhof built between 1924-1926 or Karl-Marx-Hof built between 1927-1930), the city's "Soft Urban Renewal Programme" (Sanfte Stadterneuerung) that received the UN-Habitat award in 2010, as well as current building projects in urban development areas such as Seestadt Aspern and Sonnwendviertel (Kurier 2019; Stadt Wien 2019a). Today, many European cities are suffering from tight housing markets and increasing rents, so in recent years the success of the housing market in Vienna has become ever more an object of interest. Moreover, it is clear that human geographers studying the socio-spatial effects of urban transformation processes benefit greatly through better knowledge about the place in which they themselves live. Undergraduate and graduate students in the various fields of geography at the University of Vienna, living and studying 
in such an exemplary city, not only have an obligation to take up Vienna as an object of analysis, they also have an exceptional learning opportunity at their doorstep.

The City of Vienna has grown significantly over the last decade. Due to population increases at the local level and economic transformations at the global level, new trends in urban development and local housing markets have become visible. Over four consecutive semesters, the Postdoc researchers Yvonne FrANZ and Elisabeth GRUBER have been organising three-day fieldtrips ${ }^{1)}$ for Master's students at the University of Vienna who are keen to learn from the city's recent urban development projects. Complementing the city's current housing market, past policies and projects such as the settler's movement of the early $20^{\text {th }}$ century, the legacy of Red Vienna and the Founder's Period of the late $19^{\text {th }}$ century provide further opportunities for reflecting on the past, present and future of housing market policies in Vienna.

These fieldtrips have been guided by two basic questions:

- How is the current Viennese housing market changing as a result of rising demand for housing, increasing land prices, large-scale investments in the private sector, and urban development projects subsidised by the public sector?

- How does the City of Vienna guarantee, provide for and plan affordable housing within current collaborative and contract-based planning processes in urban development areas or its soft urban renewal programme?

The same questions have also provided the structure for the discussion in this article. In addition to examining recent urban development forms and their resonance in the wider academic discourse, this article also shows how fieldtrips can be used as an important didactic tool in graduate education. On-site observation of recent urban phenomena provides a chance for students to deepen not only their theoretical but also their methodological knowledge.

\section{Setting the scene: The public and academic discourse on housing market changes in and beyond Vienna}

Students participating in the housing fieldtrips had already their own experiences in finding housing in Vienna, with many having noticed recent changes even prior to registering for the course. Finding affordable accommodation seems to have become increasingly difficult due to a rising demand for housing and rising rent prices in the city. When moving to Vienna for their university studies, many students in the courses had difficulties finding adequate or affordable accommodation. Moreover, in the last years, finding housing in the city centre has become more difficult for students. Especially the experiences of foreign students moving to Vienna from outside Austria support the above hypothesis. Since a majority of students are not (yet) eligible for social housing, this has sometimes resulted in precarious housing situations in the tight private housing market. But it is not only students who report difficulties finding affordable housing. In the public discourse, the topic of housing has also seen a remarkable increase, with wide coverage in Vienna's public media. ${ }^{2)}$

1) "Humangeographische Exkursion - Inland: Wohnen im Wandel" in spring term 2019; "Humangeographische Exkursion - Inland: Wohnen für Alle?” in winter terms 2018/19, 2017/18 and spring term 2018; see also: https://medienportal.univie.ac.at/uniview/uniblicke/detailansicht/artikel/wiener-stadtexkursion-wie-inklusiv-oder-exklusiv-ist-wohnen-in-wien/?no_cache $=1$.

2) See, for example, "Günstig war gestern. Studierende wohnen teuer" (ORF.at 2018); "Stadtforscher: Untere Einkommensgruppen werden verdrängt” (Der Standard 2018); "Zehntausende protestieren gegen hohe Mieten” (Süddeutsche Zeitung 2019); or “Man kann nicht nicht wohnen” (Zeit Online 2019). 
In addition to public discussions, recent academic discourse supports the relevancy of research on housing market changes (not only) in Vienna. A number of prominent academic journals (see Table 1 with a selection on current topics) dealing with housing issues have focussed on various related topics, including the advantages and drawbacks of home ownership, threats to and possibilities for affordable housing, how to deal with an ageing society and questions of health, the financialisation of the housing market, and reasons for and solutions to homelessness.

\begin{tabular}{|l|c|c|c|c|c|c|c|c|c|}
\hline \multicolumn{1}{|c|}{ Topic } & $\begin{array}{c}\text { Home } \\
\text { owner- } \\
\text { ship }\end{array}$ & $\begin{array}{c}\text { Afforda- } \\
\text { bility }\end{array}$ & $\begin{array}{c}\text { Ageing } \\
\text { society, } \\
\text { health }\end{array}$ & $\begin{array}{c}\text { Finan- } \\
\text { cialisa- } \\
\text { tion }\end{array}$ & $\begin{array}{c}\text { Home- } \\
\text { lessness }\end{array}$ & $\begin{array}{c}\text { Vacancy, } \\
\text { fore- } \\
\text { closure }\end{array}$ & $\begin{array}{c}\text { Com- } \\
\text { mons }\end{array}$ & $\begin{array}{c}\text { Credit, } \\
\text { mort- } \\
\text { gages }\end{array}$ & $\begin{array}{c}\text { Social } \\
\text { mix, } \\
\text { segrega- } \\
\text { tion }\end{array}$ \\
\hline $\begin{array}{l}\text { Housing } \\
\text { Policy } \\
\text { Debate }\end{array}$ & & $\mathrm{X}$ & $\mathrm{X}$ & $\mathrm{X}$ & $\mathrm{X}$ & & $\mathrm{X}$ & & \\
\hline $\begin{array}{l}\text { Housing } \\
\text { Studies }\end{array}$ & $\mathrm{X}$ & $\mathrm{X}$ & $\mathrm{X}$ & & & & & \\
\hline $\begin{array}{l}\text { Housing, } \\
\text { Theory and } \\
\text { Society }\end{array}$ & $\mathrm{X}$ & $\mathrm{X}$ & $\mathrm{X}$ & $\mathrm{X}$ & $\mathrm{X}$ & & & & \\
\hline $\begin{array}{l}\text { International } \\
\text { Journal of } \\
\text { Housing } \\
\text { Policy }\end{array}$ & $\mathrm{X}$ & & & & & & & \\
\hline $\begin{array}{l}\text { Journal of } \\
\text { Housing and } \\
\text { the Built } \\
\text { Environment }\end{array}$ & & & & & & & & & \\
\hline
\end{tabular}

Source: Own compilation. Content of articles in the latest issue of the journal as of May 27, 2019

Table 1: Key topics of discourses in academic housing journals

The current public and academic discourse has represented a basis for the fieldtrips. These topics are not restricted to Vienna, though many cities in Europe are facing challenges regarding housing affordability and access. This is due to general transformation processes such as population growth, new migration patterns, global financial investment practices and (ostensibly) limited resources for ensuring a supply of affordable housing. In growing cities, ever more households need housing, which puts pressure on local housing markets. Tightness of local housing markets and shortages of affordable housing options often result at the individual level in residential mobility being curbed, informal sharing practices, overpriced rents, overcrowding and homelessness (Franz and GruBER 2018; GRANATH HANSON and LundGREN 2019).

\subsection{Vienna's housing market from a historical perspective}

Compared to other large cities, Vienna is still considered a poster child for affordable housing. In the early $20^{\text {th }}$ century and the "Red Vienna" era, profound policy changes took place in the city, changes 
that still resonate today. Upon the social democrats gaining power in 1919, new housing market policies where implemented. The main goal of the social democratic government was improving the quality of life for workers. Among other things, this was to be reached by progressive and comprehensive social housing policies. In 1920, Vienna became an independent federal state (Bundesland), allowing the city government to raise taxes for its own use.

With the introduction of a housing tax, it became possible to finance the erection of new buildings as well as the renovation of the existing housing stock. Until 1934, mainly large housing complexes were built - the so-called Gemeindebauten, still known as the "palaces for the proletariat". These complexes provided significant improvement in living quality, sanitary conditions and educational standards for children, young people and adults. The quality standards in the Gemeindebau apartments not only involved equipping every unit with its own water supply (an unusual step, since until then water was centrally provided in buildings, at the so-called Bassena), but also with heating facilities. Providing a corrective to the devastating housing conditions of the inter-war period, Red Vienna's architecture promoted homes with "air, light and sun" and created green spaces for its population with large inner courtyards and numerous community parks (WeIHSMANN 2002; BLAU et al. 2019).

While the period of the Red Vienna ended in 1934 with approximately 60,000 flats being governed by the City of Vienna (CSENDES and OpLL 2006), the greater amount of Gemeindebauten were built after World War II. The City of Vienna stopped the construction of Gemeindebau units in 2004, but started a revival programme called Gemeindebau Neu with 3,700 planned new units in the coming years and 120 apartments ready for occupancy by the end of 2019 (Wiener Wohnen 2019).

Prior to Vienna constructing its Gemeindebauten, the housing situation was driven by private market interests as well as speculation. As a result, accommodation in Vienna was expensive and much housing for the working population was quickly built and of poor quality, for instance with regard to limited access to light and open space. The turn from the $19^{\text {th }}$ to the $20^{\text {th }}$ century was accompanied by enormous population growth. As the city became industrialised, large numbers of workers from all over the Austro-Hungarian monarchy arrived in the capital city. This so-called "Founder's Period" (Gründerzeit) experienced the highest construction of new housing units that Vienna has seen until today. Between 1856 and 1917 460,000 flats have been built (CSENDES and OpLL 2006).

This period of urbanisation was accompanied by very poor living standards for much of the population, with overcrowding, extremely poor hygienic conditions and insecure status for tenants. Buildings on the private market were in high demand, which led to extraordinarily high rents. Flats were often shared by large numbers of people; even beds were sometimes shared by workers on different shifts (the so-called Bettgehertum). Due to increasing prices of building land, landlords were interested in developing building plots with maximum investment return, which resulted in high density building. Still today, the traditional working-class neighbourhoods of the Founder's Period have very little green infrastructure such as parks or other recreation areas.

After World War I, housing scarcity intensified due to poverty, unemployment and famine. Not only did housing provided by the Red Vienna policies lead to relief. The population of Vienna also started single-handedly to occupy land and build "informal" housing on underused or unused plots, such as former military grounds. The so-called settler's movement (Siedlerbewegung), featuring self-sufficiency through vegetable gardens and animal husbandry, became a famous example for a "bottom-up" housing initiative. By 1936, approximately 5,000 "settlers" lived in so-called Bretteldörfer across Vienna (HAUER and KRAMMER 2019).

Today, about 220,000 flats (about 30 percent of all flats in the city) are owned by the City of Vienna, providing public housing to almost 25 percent of the population (Magistrat der Stadt Wien 2015a). Even after the Red Vienna period, the city continued to build public housing, although since the 1980s, investments in such housing have become less, with the city increasingly supporting 
both non-profit and for-profit housing co-operations that construct and maintain housing. These subsidized houses host around 200,000 flats, representing approximately another third of the total housing stock in Vienna (Stadt Wien 2017). Although this social housing has a significant curbing impact on the price of rents in the city, around 47 percent of the Viennese population live in housing on the private market (Magistrat der Stadt Wien 2015b); many of them in buildings dating back to the Founder's Period.

\subsection{Identifying the core housing market segments in Vienna}

Historical developments have caused various types of housing market segments to be distributed across Vienna. During our fieldtrips, visiting distinct segments of the housing market has been crucial. Students learn about these historic developments and - still more importantly - about the current challenges facing the different segments of the housing market today.

An example for the public housing market is served by a traditional public housing complex: the Reumannhof (Fig. 1). Representing a "superblock", it was built in the Red Vienna era between the years 1924 and 1926 (Wiener Wohnen 2019b). It was one of the first Gemeindebauten to be realised. Already in the past, the availability of public housing was tied to certain regulations, since

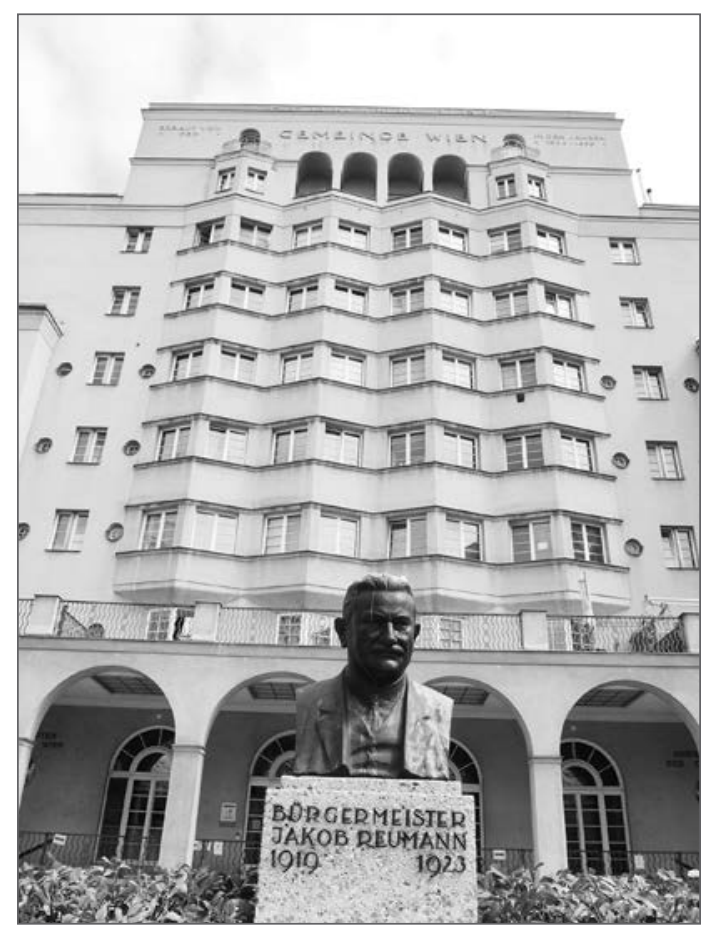

Photo: Y. Franz, 2019

Figure 1: The iconic "Reumannhof" located in the $5^{\text {th }}$ district of Vienna. Dating to the Red Vienna era, the complex contains several public housing buildings 
such housing is designed for those in need. Actually, to receive a flat from the municipality, people must fulfil specific requirements (e.g., being a resident of the city for at least two years, holding EU citizenship or a similar resident permit, having a certain maximum income). Additionally, applicants must present a clear reason for "being in need of a flat" (Begründeter Wohnraumbedarf), such as having to move out of the parents' home, the old apartment being over-crowded, or accessibility problems due to handicaps (Wohnberatung Wien 2019).

In addition to iconic housing projects of "Red Vienna", also housing complexes in the subsidised housing sector were visited during our fieldtrips. A well-known example is the "Alt-Erlaa" complex, built during the 1970s (Fig. 2). The idea of the project was to provide an alternative to suburbanisation trends, offering within the city relatively large apartments with a broad range of amenities, such as indoor and roof-top pools, saunas, playgrounds and other green spaces, as well as a commercial infrastructure in a large shopping centre on the ground floor of the complex. The architect Harry Glück referred to the apartment complex of more than twenty stories as "stacked single-family houses" (HABARTA 2018) Housing complexes built by non-profit developers are often orientated still today on principles that were introduced during the Red Vienna period, such as plentiful recreational areas and green spaces, and inner courtyards as central elements. In Alt-Erlaa, all of the flats have terraces or balconies in addition to the already mentioned common spaces.

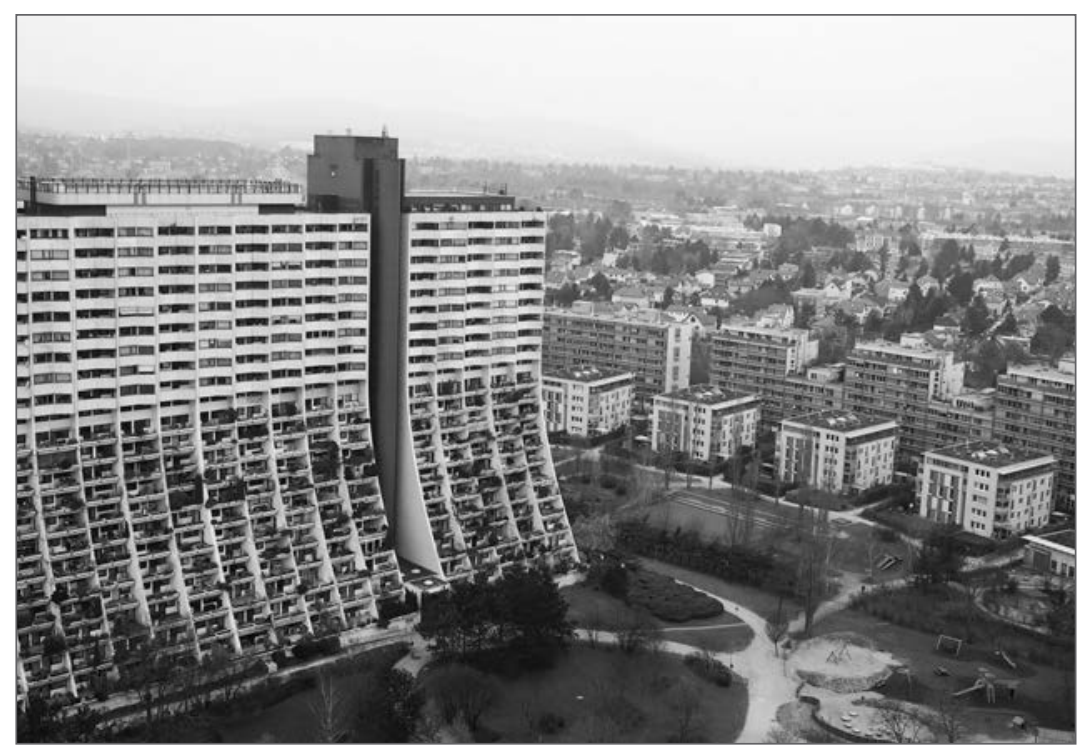

Photo: Y. FranZ, 2018

Figure 2: The "stacked single-family houses" of "Alt-Erlaa", and its placement in the wider neighbourhood

The area of the so-called Auf der Schmelz (Fig. 3) is a traditional example for land that became "informally" used during the settlers' movement. Still today, small single-family houses and gardens are found in this part of $15^{\text {th }}$ district, which is on the other hand one of the most densely-populated districts of Vienna. Numbers of Viennese first began to squat on the former military grounds during World War I, using the land for housing and growing their own vegetables. During the Red Vienna 
period, the city legalised the settlement as a leisure area of allotment gardens (Kleingartensiedlung) (KGV Zukunft 2019). While originally, people were officially allowed to use the plots in the Schmelz area for leisure purposes only, from the 1970s more and more former gardens have been transformed into homes that can be used for permanent living. This has resulted in an increased demand for such gardens and long waiting lists.

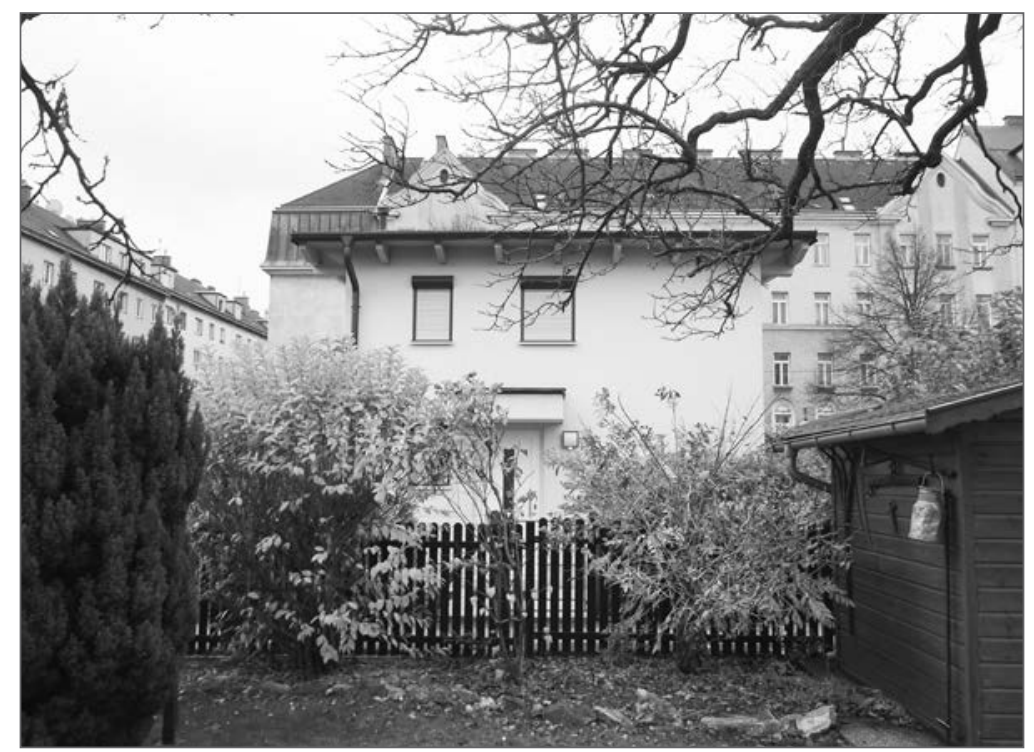

Photo: $\quad$ Y. Franz, 2017

Figure 3: A single-family house in the allotment garden settlement "Auf der Schmelz" and its surrounding neighbourhood, consisting of public housing (Gemeindebauten) (left) and Founder's Period buildings (right)

\subsection{Current challenges of Vienna's housing market}

The current increase of housing demand in Vienna is a direct result of the city's growing population. Prior to a phase of "re-urbanisation", it was mainly the suburban surroundings of the city that increased in population (see SUITNER et al. 2018; EDER et al. 2018). But since the turn of the $21^{\text {st }}$ century, especially since 2008, the City of Vienna has been growing dynamically due to high numbers of incoming migration from other European Union countries as well as third countries. Between 2015 and 2016, a large number of asylum seekers also arrived in the city (BAUER et al. 2018; GRUBER 2018).

Additionally, rising financial interest in the real estate market has led to an increase in land prices, not only in Vienna but also in other cities around the world. Since the financial crisis of 2008, in particular, the increasing interest of private and institutional capital investment in the real estate market has become a substantial driver of gentrification. In Vienna, this has resulted in a softening of the federal rent regulation system and pressure being put on de-commodifying the social housing market (Franz 2015; KADI 2015; MATZNETTER 2019). 
The real estate market currently offers stable yet attractive investment opportunities in terms of interest rates and rates of return. Often described as "concrete gold", housing has developed in the last years from being a basic human need to becoming an investment opportunity. This has hindered the supply of affordable housing and stimulated counter-reactions, such as the European Citizen Petition "Housing for All" (ECP 2019). In the last years, the private housing market in Vienna is probably the segment of the economy that has experienced the most significant transformation. Private market interests have been supported due to older building stock being in need of renovation, but also due to increasing housing demands.

The biggest challenges of the housing market in Vienna today were discussed during the fieldtrip and can be found in temporary rent contracts and the increasing prices of rents and ownership on the private market. While rents in buildings constructed prior to 1945 are regulated by a national rent regulation law (Mietrechtsgesetz), flats in post-1945 buildings do not fall under rent regulation and thus are subject to open market prices. This has prompted the private investment market to construct new housing, as for example by converting attic spaces into roof-top flats, or by demolishing old buildings and replacing them with new (Fig. 4). These new buildings are often more dense in terms of apartment size and floor plans. This results in aesthetic changes of the built environment in Founder's Period districts that were discussed with the participants during the fieldtrip. With the increasing prices of building-dedicated land in inner-city locations, to profit from new construction, (serviced) luxury apartment buildings are an emerging trend in Vienna (Fig. 5). In brief, the specific challenges in the private housing market are driven by increasing housing demand as well as investment prospects.

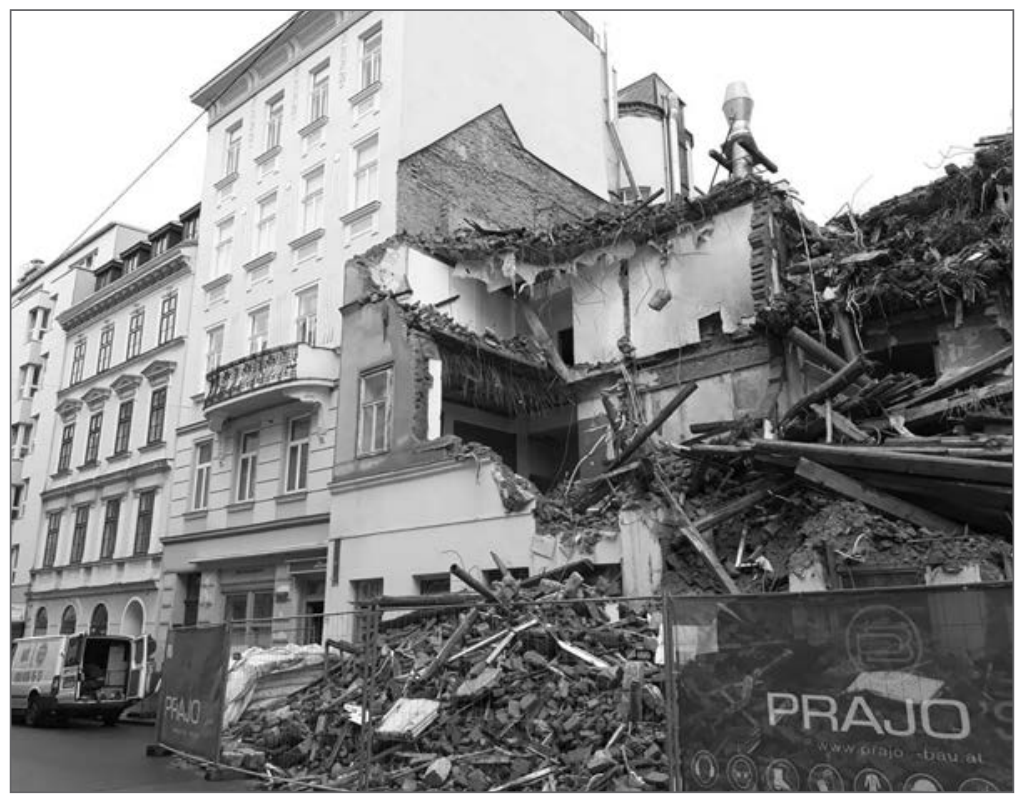

Photo: $\quad$ E. GRUBER, 2018

Figure 4: Pre-1945 buildings are often demolished to replace them with new buildings with rents, unregulated by the Mietrechtsgesetz and usually with a higher density (by increased heights and the amount of storeys). 


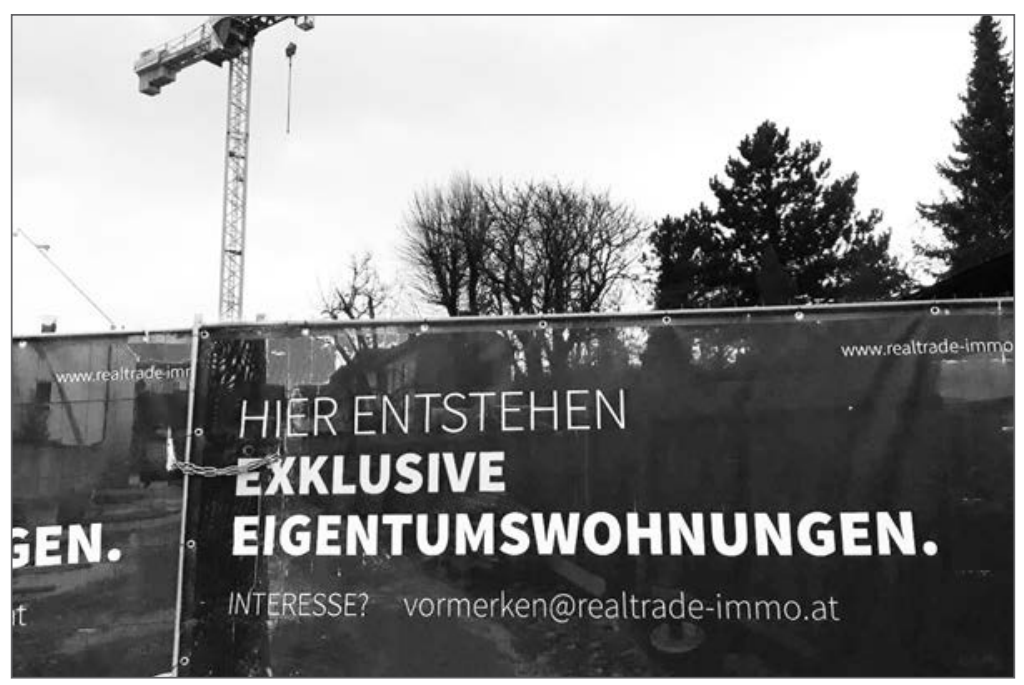

Photo: E. GRUBer, 2018

Figure 5: Especially in expensive locations, the emergence of "luxury" or "exclusive" apartments is commonly visible in Vienna today

In contrast to the private housing market, the "social housing market" in Vienna remains an important tool for restraining rent prices. Still today, it fulfils the criteria of social housing understood in the strict academic sense as a system catering to households with limited financial resources by means of a distribution system that provides long-term housing at below-market rents or prices (Granath HANSSON and LundGrEn 2019, S. 162). The underlying ideology is to provide vulnerable groups decent and affordable accommodation, with such "vulnerable groups" generally understood as those who "by virtue of their age, sex, race, socioeconomic or physical condition find obstacles for their integration in a certain institutional or social context [... and are] exposed to high risk of being socially excluded" (UNCETA et al. 2019, p. 6).

Although Vienna is well known for its extensive social housing market, which amounts to nearly 40 percent of the entire housing stock (KADI and VerLIČ 2019, p. 35), such housing is not available for all vulnerable groups living in the city. This segment of social housing is highly exclusionary with regard to access barriers (such as "self-funding" entry fees [Eigenmittelanteil], application procedures and waiting lists). Eligibility criteria (FrANZ and GrUBER 2018) often limit newcomers and migrants to options in this section of the housing market, although it has been undergoing noteworthy changes with regard to affordability stimulated by the demand for housing due to significant population growth. Additionally, changes in the national rent regulations scheme (such as the possibility of temporary instead of unlimited rent contracts) (see MATZNETTER 2019) and increasing global capital investment support the tight housing market in Vienna.

Currently, changes in both the social and private housing segments are causing severe challenges to accessing the housing market, finding affordable housing options and establishing permanent housing situations. As a consequence, new vulnerable groups are emerging, such as single person headed family households, young adults remaining longer in semi-dependent structures with their parents (DrUTA et al. 2019), elderly households, recognised refugees and people granted subsidiary protection (AIGNER 2018). Such groups face higher risks of poverty as their housing expenses often 
exceed a quarter or more of their household income (see REINPRECHT 2019) while it is generally thought that housing expenses should not exceed 30 percent of a household's income.

\section{Governance: Strategies of the City of Vienna for future affordable housing}

The City of Vienna is currently developing a set of policies designed to provide affordable housing for today and in the future. Most of the target areas of its urban development plan (Stadtentwicklungsplan - STEP) involve newly built neighbourhoods. In the northern part of Vienna, in the Seestadt Aspern project on the far side of the Danube, 20,000 new flats will be realised by the year 2028. This project and the Sonnwendviertel project, near Vienna's main train station in the $10^{\text {th }}$ district, are the developments best known in and outside Vienna. But a number of other new housing projects are also being planned and realised, such as the Nordbahnhof area in the $2^{\text {nd }}$ and $20^{\text {th }}$ districts, and the area known as "In der Wiesen Süd" in the $23^{\text {rd }}$ district (see Stadt Wien 2019b).

\subsection{Newly-built social housing at the city edges}

The planning process of most of the current urban development sites started already in the early 2000s or before, when the population of Vienna began to grow sharply. While previous decades also saw urban development, the dimensions of the current projects are much larger, since housing demands have become significantly higher. In part, this is also due to lifestyle changes, as for example more people living in single-person households. A "smaller" yet interesting project visited during a fieldtrip in 2019 is the former site of a gas plant in Vienna's 21 ${ }^{\text {st }}$ district (Gaswerk Leopoldau) (Fig. 6). In total, 1,400 housing units are currently under construction, combined with various types of new infrastructure such as long-distance heating and public spaces (see Gebietsbetreuung Stadterneuerung 2019; Neu Leopoldau 2019).

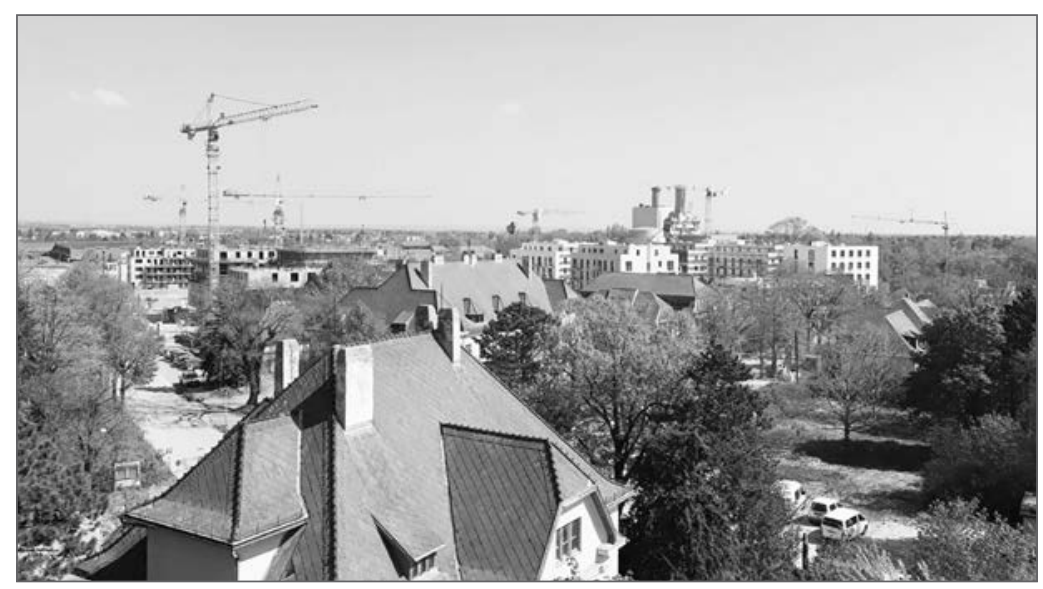

Photo: $\quad$ E. GRUBer, 2019

Figure 6: The housing project at the old gas plant in Leopoldau in the $21^{\text {st }}$ district will be finished by the end of 2019. The new buildings are being integrated into the existing buildings of the former gas plant 
A masterplan has been developed for the Neu Leopoldau urban development site by a consortium of different city departments. Subsequently, potential for-profit and non-profit housing developers have been invited to enter a competition (Bauträgerwettbewerb) to present housing projects for the different building plots. The successful projects have been chosen based on criteria such as economic and ecological efficiency, architectural innovation, and social sustainability. The chosen projects will receive residential building subsidies from the City of Vienna (Wiener Wohnbauförderung).

In 2019, the City of Vienna broadened its regulations for subsidised housing in the city, since until then only areas being developed by the city had compulsory project contests and a share of non-profit developers. To increase the amount of land where public-supported housing (Geförderter Wohnbau) can be realised, the city has introduced a new zoning category.

\subsection{Renovated housing in built-up inner-city areas}

In addition to constructing new apartment buildings, the city has also implemented policies to protect the old housing stock, mainly the one from the Founder's Period. In the 1970s, Vienna's "soft urban renewal" planning programme was introduced as a special subsidy opportunity for private building owners. It enabled building renovation to be done with only limited increases in rent prices. By introducing loans for renovating old building stock, it was attempted to minimise common negative consequences of urban renewal, such as the displacing of tenants. Procurement conditions for loans include freezing rents for fifteen years at the same price levels as buildings subsidised by the city (FöRSTER 2005).

Due to such policies targeting the private housing market, Vienna has seen lower rent increases than in other European cities (Franz 2015). However, the influx of (international) investment capital in the last years as well as comparably low interest rates in financial markets have resulted in the "soft urban renewal" programme becoming less popular. Moreover, private owners are often

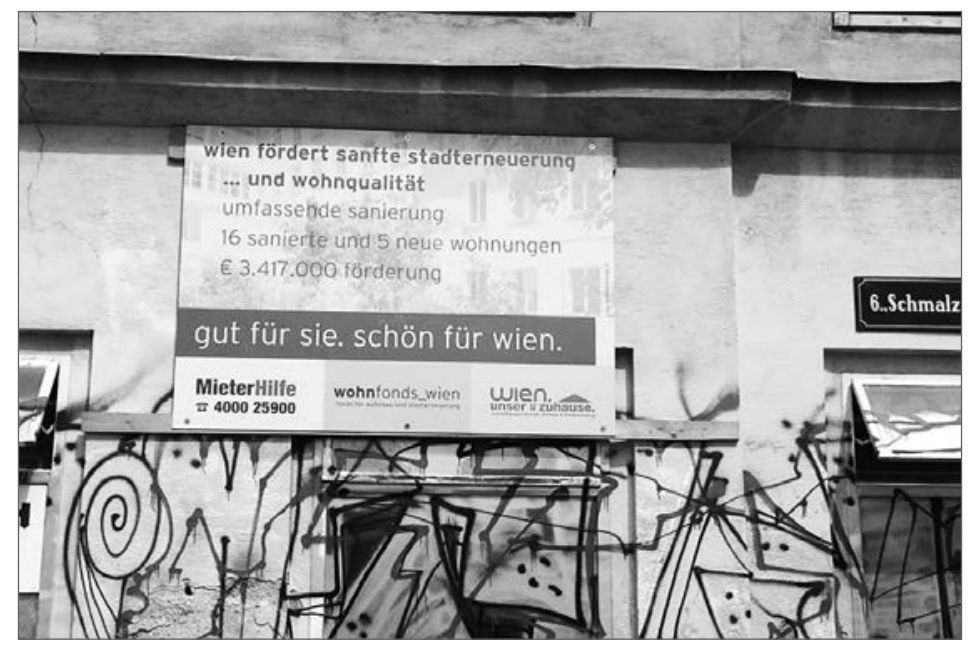

Photo: Y. Franz, 2019

Figure 7: Advertising for Vienna's "soft urban renewal programme" can be found on the facades of buildings prior and under renovation 
dissuaded from opting for public subsidies due to the high level of administrative output involved and the long duration of the process as we were discussing during the fieldtrip.

\section{Didactic benefits of fieldtrips for studying spatial development processes}

When studying human geography, the housing market represents an excellent research topic since it touches on so many relevant aspects: economic geography, (urban) planning, population geography, history, as well as political sciences. With the urban housing market serving as a prime learning case, the didactic potential of fieldtrips should not be underestimated. With the lecture halls of the university left behind, fieldtrips provide "learning environments outside of schools" (außerschulische Lernorte, see ERHORN and SCHWIER 2016). This allows for a mix of methodology, such as expert input and gathering of independent observations, as well as theory-led on-site discussions that stimulate the critical assessment of spatial processes. "Experiencing to gain new knowledge" is an established didactic tool in the study of geography. It can entail three approaches: a) the "overview fieldtrip", b) the "work fieldtrip", and c) the "searching for traces fieldtrip" (Dickel and SCHARVOGEL 2013, pp. 176ff).

It is especially important for students of human geography, urban studies, and planning to have direct contact with the different stakeholders involved in urban and regional development processes. Fieldtrips offer a fine opportunity for meeting and getting into contact with them. By talking to relevant persons - be it on the side of politics or policy competency (e.g., in the case of Vienna, officials in city departments) or the side of the economy (e.g., private housing market developers) - it is possible to experience the different spheres of the various stakeholders. Fieldtrips offer opportunities for thinking about internships or future employment. While in the field, it is also possible to develop research topics for bachelor's or master's theses. For students who plan to become teachers, the housing market offers an excellent learning tool that can be taken into future classrooms.

The students' online evaluations following the fieldtrips have shown how successful the method is with regard to communicating and gaining new knowledge. The students particularly appreciated the mix of locations and examples, as well as the diversity of the didactic tools, which ranged from lectures by specialists and walking tours, to on-site reflections and role-playing exercises. Since the focus of the fieldtrips touches the lives of students directly, they particularly valued education processes that resulted in direct action, as for example learning how to subscribe to the Wien Ticket to gain access to the social housing market in Vienna. Especially the new smart flats offered by the City of Vienna received a great deal of interest, since for newly built flats with unlimited rental contracts, the rents are comparably low.

\section{Lessons learned: Conclusions from the field}

The "Housing in Vienna" fieldtrips organised by the Department of Geography and Regional Research at University of Vienna between 2017 and 2019 have shown that fieldtrips are a substantial learning tool for students. Especially with regard to the current and rapidly changing developments in Vienna's housing market, fieldtrips allow the topic to be approached in a variety of ways. This article has presented various aspects of Vienna's housing market, including rising demands for housing, increasing land prices, large-scale investments in the private sector, and urban development projects subsidised by the public sector. In addition, the fieldtrips have examined how the City of Vienna plans, generates, and provides affordable housing through its soft urban renewal programme as well as through collaborative and contract-based planning processes of urban development sites. 
The Viennese housing market offers an especially good overview of urban housing, since all important segments and forms of housing are found in the city: from the historical and well-established social housing sector, to the emergence in recent years of private market interests as well as new instruments of city-funded housing construction and renovation of existing housing stock. The range of different housing options in Vienna and their shift in importance over time, either as "exclusive" or "inclusive", makes the city's housing market an ideal pedagogic tool. Fieldtrips provide an excellent learning experience for students. Offering chances for direct contact with stakeholders and for visiting development sites, they are an outstanding instrument for research led teaching.

\section{References}

Aigner A. (2018): Housing Entry Pathways of Refugees in Vienna, a City of Social Housing. In: Housing Studies, 34 (5), pp. 779-803. - https://doi.org/10.1080/02673037.2018.1485882.

Bauer R., Fendt C., Haydn G., Remmel W., Seibold E. (2018): Kleinräumige Bevölkerungsprognose Wien 2018. Wien: Magistratsabteilung 23 (MA 23), Stadt Wien (= Statistik Journal Wien 1/2018).

Blau E., Heindl G., Platzer M. (2019): Architektur und Politik. Lernen vom Roten Wien. Debatte. In: Schwarz W. M., Spitaler G., Wikidal E. (eds.): Das Rote Wien 1919-1934. Basel: Birkhäuser, pp. 158-165.

Csendes P., Opll F. (eds.) (2006). Wien: Geschichte einer Stadt. Vol. 3: Von 1790 bis zur Gegenwart. Wien: Böhlau.

Der Standard, Newspaper (April 10, 2018): Stadtforscher: "Untere Einkommensgruppen werden verdrängt". - https:// derstandard.at/2000077611874/Stadtforscher-Untere-Einkommens gruppen-werden-verdraengt (last accessed: June 23, 2019).

Dickel M., Scharvogel M. (2013): Geographische Exkursionspraxis: Erleben als Erkenntnisquelle. In: KANwISCHER D. (ed.): Geographiedidaktik. Ein Arbeitsbuch zur Gestaltung des Geographieunterrichts. Stuttgart: Gebr. Borntraeger, pp. 176-185 (Studienbücher der Geographie).

Druta O., Limpens F., Pinkster F. M., Ronald R. (2019): Early Adulthood Housing Transitions in Amsterdam. Understanding Dependence and Independence Between Generations. In: Population, Space, and Place, 25 (2), e2196, pp. 1-11. - https://doi.org/10-1002/psp. 2196.

ECP - European Citizen Petition (2019): Housing for All. - https://www.housingforall.eu/at/ unterstuetzen-sie-die-kampagne-und-unterzeichnen-sie-die-petition/ (last accessed: June 23, 2019).

Eder J., Gruber E., Görgl P., Hemetsberger M. (2018): Wie Wien wächst: Monitoring aktueller Trends hinsichtlich Bevölkerungs- und Siedlungsentwicklung in der Stadtregion Wien. In: Raumforschung und Raumordnung, 76 (4), pp. 327-343.

Erhorn J., Schwier J. (2016): Pädagogik außerschulischer Lernorte. Eine interdisziplinäre Annäherung. Bielefeld: Transcript.

FöRSTER W. (2005): Stadterneuerung zwischen Markt und Staat: Der Wiener Weg im internationalen Vergleich. In: Perspektiven. Dialog von Wissenschaft und Politik, 7-8/2005, pp. 22-28.

Franz Y. (2015): Gentrification in Neighbourhood Development. Case Studies from New York City, Berlin and Vienna. Göttingen: V\&R unipress / Vienna University Press.

Franz Y., Gruber E. (2018): Wohnen "für alle" in Zeiten der Wohnungsmarktkrise? Der soziale Wohnungsbau in Wien zwischen Anspruch und Wirklichkeit. In: Standort. Zeitschrift für Angewandte Geographie 42 (2), pp. 98-104. - https://link.springer.com/article/10.1007/ s00548-018-0533-1 (open access). 
Gebietsbetreuung Stadterneuerung (GB Stern) (2019): Stadtteilmanagement Neu Leopoldau: Neues entsteht in Neu Leopoldau. - https://www.gbstern.at/themen-projekte/stadtteil management-in-neubaugebieten/stadtteilmanagement-neu-leopoldau/ (last accessed: June 25, 2019).

Granath Hansson A., Lundgren B. (2019): Defining Social Housing: A Discussion on the Suitable Criteria. In: Housing, Theory and Society, 36 (2), pp. 149-166.

Gruber E. (2018): Urban Planning: A Vienna Case Study. In: Villa M. (ed.): Global Cities and Integration, a Challenge for the Future. Milan: Ledizioni LediPublishing, pp. 155-176.

HABARTA G. (2018): Harry Glück: Schriften zur Architektur für Menschen. Norderstedt: Fantart publishing.

Hauer F., Krammer A. (2019): Wilde Siedlungen und rote Kosakendörfer. Zur informellen Stadtentwicklung im Wien der Zwischenkriegszeit. In: Schwarz W. M., Spitaler G., Wikidal E. (eds.): Das Rote Wien 1919-1934. Basel: Birkhäuser, pp. 170-175.

KADI J. (2015): Re-commodifying Housing in Formerly 'Red Vienna'?. In: Housing, Theory and Society, 32 (3), pp. 247-265. - https://doi.org/10.1080/14036096.2015.1024885.

KADI J., VERLIČ M. (2019): Gentrifizierung am privaten Wiener Wohnungsmarkt. In: Kadi J., VeRLIČ M. (eds.): Gentrifizierung in Wien. Perspektiven aus Wissenschaft, Politik und Praxis. Wien: Kammer für Arbeiter und Angestellte, pp. 35-50 (= Stadtpunkte, 27).

KGV Zukunft - Kleingartenverein Zukunft (2019): Chronik. - https://www.kgv-zukunft.at/chronik/ (last accessed: June 26, 2019).

Kurier, Newspaper (May 5, 2019): "Voneinander lernen ist wichtig". Isabella Jandl koordiniert internationale Delegationen zum Thema Wiener Wohnen. - https://kurier.at/chronik/wien/ wohnkurier/voneinander-lernen-ist-wichtig/400483684 (last accessed: May 27, 2019).

Magistrat der Stadt Wien (2015a): Dauerhaft preisgünstiger Wohnraum: Sozialer Wohnbau in Wien. Wien: Stadt Wien, Magistratsabteilung 50 - Referat für Wohnbauforschung und internationale Beziehungen.

Magistrat der Stadt Wien (2015b): Wien im Querschnitt der Zeit. Ergebnisse aus der Registerzählung 2011. Teil 1 - Gebäude- und Wohnungszählung. Wien: Stadt Wien, Magistratsabteilung 23 (= Statistik Journal 2/2015).

MatZnetTer W. (2019): 100 Jahre Mieterschutz: Ein Instrument zur Steuerung von Gentrifizierung. In: Kadi J., Verlič M. (eds.): Gentrifizierung in Wien. Perspektiven aus Wissenschaft, Politik und Praxis. Wien: Kammer für Arbeiter und Angestellte, pp. 13-24 (= Stadtpunkte, 27).

Neu Leopoldau Entwicklungs GmbH (2019): Neu Leopoldau. - http://www.neuleopoldau.at/ \#Wohlfahrtsgebaeude/2383 (last accessed: June 25, 2019).

ORF.at, Österreichischer Rundfunk (Sept. 24, 2018): Günstig war gestern. Studierende wohnen teuer. - https://orf.at/stories/3022801/ (last accessed: June 23, 2019).

ReInPReCht C. (2019): Wohnen und die Fragmentierung des Sozialen: Gentrifizierung als Symptom gesellschaftlicher Transformation. In: KAdi J., VerLič M. (eds.): Gentrifizierung in Wien. Perspektiven aus Wissenschaft, Politik und Praxis. Wien: Kammer für Arbeiter und Angestellte, pp. 25-34 (= Stadtpunkte, 27).

Stadt Wien, Geschäftsgruppe Wohnen, Wohnbau und Stadterneuerung (2017): Wiener Wohnbau. Jahresbericht 2017. - https://www.smartertogether.at/wp-content/uploads/2018/05/WienerWohnbau-Jahresbericht-2017.pdf (last accessed: June 25, 2019).

Stadt Wien (2019a): Internationale Delegationsbesuche. - https://www.wien.gv.at/kontakte/md-eui/ delegationen.html (last accessed: May 27, 2019).

Stadt Wien (2019b): Vorhaben und Projekte der Wiener Stadtentwicklung. - https://www.wien.gv.at/ stadtentwicklung/projekte/ (last accessed: May 25, 2019). 
Süddeutsche Zeitung (April 6, 2019): Zehntausende protestieren gegen hohe Mieten. - https://www. sueddeutsche.de/politik/miete-protest-volksbegehren-1.4399213 (last accessed: June 23, 2019).

Suitner J., Krisch A., PÜhringer F. (2018): TRANS[form]DANUBIEN. Eine urbane Metamorphologie der Wiener Stadtplanung anhand der Entwicklungsdynamik Wiens links der Donau. Abschlussbericht zum Forschungsprojekt. Wien: Technische Universität Wien, Department für Raumplanung.

Unceta A., Luna Á, Castro J., Wintues R. (2019): Social Innovation Regime: An integrated Approach to Measure Social Innovation. In: European Planning Studies. Online First. - https:// doi.org/10.1080/09654313.2019.1578338.

Weinsman H. (2002): Das Rote Wien. Sozialdemokratische Architektur und Kommunalpolitik 1919-1934. Wien: Promedia.

Wiener Wohnen (2019a): Gemeindebau Neu. - https://www.wienerwohnen.at/gemeindebauneu. html (last accessed: July 15, 2019).

Wiener Wohnen (2019b): Reumannhof. - https://www.wienerwohnen.at/hof/93/Reumannhof.html [last accessed: June 25, 2019].

Wohnberatung Wien (2019): Wiener Wohnticket. - https://www.wohnberatung-wien.at/wienerwohn-ticket/allgemeines/ (last accessed: June 25, 2019).

Zeit Online (June 18, 2019): Man kann nicht nicht wohnen. - https://www.zeit.de/wirtschaft/2019-06/ mietendeckel-berlin-landesregierung-wohnungsmarkt (last accessed: June 23, 2019). 